\title{
Antioxidant Activity Potential of Red Pomegranate (Punica granatum L.) Peel as Herbal Tea
}

\author{
Prima Vina Resti ${ }^{* 1}$, Sri Utami ${ }^{2}$, Arsyad $^{3}$ \\ ${ }^{1}$ Faculty of Medicine, YARSI University. Universitas Yarsi Kav. 13, Jalan Letjen Suprapto, Kota Jakarta Pusat, Daerah Khusus \\ Ibukota Jakarta, Indonesia 10510 \\ 2Departement of Biochemistry, Faculty of Medicine, YARSI University. Universitas Yarsi Kav. 13, Jalan Letjen Suprapto, Kota \\ Jakarta Pusat, Daerah Khusus Ibukota Jakarta, Indonesia 10510 \\ ${ }^{3}$ Departement of Islamic Studies, Faculty of Medicine. YARSI University Universitas Yarsi Kav. 13, Jalan Letjen Suprapto, \\ Kota Jakarta Pusat, Daerah Khusus Ibukota Jakarta, Indonesia 10510
}

DATA OF ARTICLE:

Received: 11 Feb 2020

Reviewed: 01 Mar 2020

Revised: 11 Jun 2020

Accepted: 27 Jun 2020

*CORRESPONDENCE:

primvir@ymail.com

DOI:

10.18196/mm.200245

TYPE OF ARTICLE:

Research

\begin{abstract}
Red pomegranate (Punica granatum L.) contains punicalagin (elagitanin) which has strong antioxidant activity. This study aims to examine the antioxidant activity of steeping tea from red pomegranate peel. This research is observational with red pomegranate peel as the research object. The red pomegranate peel is processed into simplicia, then some of the simplicia is brewed in boiling water at $100{ }^{\circ} \mathrm{C}$ and the other part is made of ethanol extract. Steeping tea and ethanol extract at a dose of $1.25 ; 2.5 ; 5 ; 10$; and 20 ppm were measured for its antioxidant activity by the 2,2-diphenyl-1-picryl-hydrazyl-hydrate (DPPH) method. As a control, ascorbic acid was used. The antioxidant activity is expressed in $\mathrm{IC}_{50}$. Data were analyzed by one-way Analysis of Variance. The results showed that the $\mathrm{IC}_{50}$ of steeping tea was $17.59 \mathrm{ppm}$, ethanol extract was $9.58 \mathrm{ppm}$, and ascorbic acid was $2.98 \mathrm{ppm}$. There was no significant difference in the $\mathrm{IC}_{50}$ between brewed tea, ethanol extract and ascorbic acid $(p=0.05)$. It was concluded that $P$. granatum $L$ peel in the form of tea infusion had lower antioxidant activity than the ethanol and ascorbic acid extracts, but statistically all three showed the same strong antioxidant activity.
\end{abstract}

Keywords: antioxsidant, DPPH, Punica granatum L., ethanol extract, $\mathrm{IC}_{50}$, tea.

Abstrak: Buah delima merah (Punica granatum L) mengandung punicalagin (elagitanin) yang memiliki aktivitas antioksidan kuat. Penelitian ini bertujuan untuk mengkaji aktivitas antioksidan seduhan teh dari kulit delima merah. Penelitian bersifat observasional dengan kulit delima merah sebagai obyek penelitian. Kulit delima merah diolah menjadi bentuk simplisia, kemudian sebagian simplisia diseduh dalam air mendidih $100{ }^{\circ} \mathrm{C}$ dan sebagian lainnya dibuat ekstrak etanol. Seduhan teh dan ekstrak etanol pada dosis $1.25 ; 2.5 ; 5 ; 10$; dan 20 ppm diukur aktivitas antioksidannya dengan metode 2,2-diphenyl-1-picryl-hydrazylhydrate (DPPH). Sebagai kontrol digunakan asam askorbat. Aktivitas antioksidan dinyatakan dalam $\mathrm{IC}_{50}$. Data dianalisis dengan Analisis Varians satu jalan. Hasil penelitian menunjukkan $\mathrm{IC}_{50}$ seduhan teh sebesar 17.59 ppm, ekstrak etanol sebesar $9.58 \mathrm{ppm}$, dan asam askorbat sebesar $2.98 \mathrm{ppm}$. Tidak ada perbedaan signifikan $\mathrm{IC}_{50}$ antara seduhan teh, ekstrak etanol dan asam askorbat $(\mathrm{p}=0.05)$. Disimpulkan bahwa kulit delima merah dalam bentuk seduhan teh memiliki aktivitas antioksidan lebih rendah daripada ekstrak etanol dan asam askorbat, tetapi secara statistik ketiganya menunjukkan aktivitas antioksidan yang sama kuat. Kata Kunci: antioksidan, DPPH, Punica granatum L., ekstrak etanol, IC $_{50}$, teh

\section{INTRODUCTION}

As we are getting older, the body's function and ability to adapt to organs damage will decrease. ${ }^{1}$ There are two factors which play a role in the aging process namely internal and external factors. Internal factors include free radicals, reduced hormones, glycosylation processes, apoptosis, decreased immune system, and genes. 
External factors are an unhealthy lifestyle, including unhealthy diets, wrong habits, environmental pollution, radiation, ultraviolet (UV) rays, cigarette smoke, and stress. ${ }^{2,3}$

Continuous exposure to UV rays can cause damage to the structure and function of the skin, thereby accelerating the skin aging process. ${ }^{2,4}$ One of the most developed theories of aging is the theory of free. This theory explains, an organism gets old because of the accumulated damage by free radicals in the cells over time. Free radicals will damage molecules whose electrons are attracted by these free radicals, causing cell damage, impaired cell function, and even cell death. 5 Free radicals that cause skin aging come from solar UV radiation. In living cells, solar UV radiation generates free radicals that can cause various chemical photo risks such as photo isomerization and photo oxidation. Photo oxidation reactions occur due to the release of Reactive Oxygen Species (ROS) in the form of superoxide anions (O2), hydrogen peroxide $\left(\mathrm{H}_{2} \mathrm{O}_{2}\right)$ and hydroxyl radicals $(\mathrm{OH})$ by chromophores that absorb ultraviolet light. ${ }^{6}$

Free radicals can be inhibited by antioxidants. The inhibition process is carried out by reducing the level of free radical reactivity by compounds that acts as an antioxidant. ${ }^{7}$ Red pomegranate (Punica granatum L.) is one of the natural antioxidants. Red pomegranate is a source of polyphenol antioxidants, especially punicalagin (elagitanin) which has been shown to have strong antioxidant, anti-inflammatory, and anticarcinogenic activity in several studies. ${ }^{8,9}$

Various diseases, that are the target of research to find out the benefits of pomegranate, are various types of inflammatory diseases, antioxidants, degenerative diseases, various types of cancer and the regulation of the fibrosis process. ${ }^{10}$ Pomegranates juice and peel have been shown to have antioxidant and anti-cancer activity. ${ }^{11}$

Tea is a famous beverage among Indonesians. The ingredients used to make tea also vary with the respective benefits and advantages. Tea products can not only be produced from tea leaves but also from other plants such as red pomegranate ( $P$. granatum $L)$. This study aims to examine the antioxidant activity of steeping tea from $P$. granatum peels.

\section{MATERIALS AND METHOD}

This research was an observational study with red pomegranate peel made of tea and ethanol extract. Pomegranate peel was dried, cut into small pieces, and crushed to form simplicia.
Most of the simplicia was brewed with boiling water at $100^{\circ} \mathrm{C}$ to form tea, some of the simplicia was macerated with $70 \%$ ethanol and filtered, the filtrate was concentrated, and the red pomegranate peel extract was obtained. Steeping tea and ethanol extract dose of $1.25 ; 2.5 ; 5 ; 10 ; 20$ ppm of antioxidant activity was measured by using the DPPH method and ascorbic acid was used as a comparison. The antioxidant activity was expressed by the IC50 value. Data were analyzed by oneway Anava test.

Making Tea from Red Pomegranate Peel. Red pomegranate peel powder that has been mashed in a blender, separated between the smooth and the coarse. As much as $33 \mathrm{mg}$ of fine powder, put into a beaker glass, and poured with 33 $\mathrm{mL}$ of boiling water at $100^{\circ} \mathrm{C}$, the mixture was stirred at 900 rpm for 5 minutes, then filtered using filter paper to obtain a stock solution of the simplicia test with a concentration of $1000 \mathrm{ppm}$.

Preparation of $70 \%$ Ethanol Extract from Pomegranate Peel. $105 \mathrm{~g}$ of red pomegranate peel powder was put into a $500 \mathrm{~mL}$ Erlenmeyer flask, then $500 \mathrm{~mL}$ of $70 \%$ ethanol solvent was added, centrifuged for 6 hours using a shaker, and filtered to obtain the filtrate. $500 \mathrm{~mL}$ of ethanol solvent was added back into the Erlenmeyer flask containing the residue and left to stand for 24 hours. Then done the same way for 3 days. The filtrate was evaporated with a vacuum rotary evaporator at a temperature of $500 \mathrm{C}$ to obtain a thick extract. ${ }^{13,14} \mathrm{~A}$ sample of $10 \mathrm{mg}$ extract was dissolved with methanol up to $10 \mathrm{~mL}$ into a $1000 \mathrm{ppm}$ stock solution.

Preparation of DPPH Solution. DPPH with a concentration of $160 \mathrm{mg} / \mathrm{L}$ was prepared by weighing the substance as much as $4.0 \mathrm{mg}$ and dissolving it in $25 \mathrm{~mL}$ of methanol. The solution was then stored in a dark room and protected with aluminum foil.

\section{Preparation of Ascorbic Acid Solution.}

Ascorbic acid was used as a positive control. As much as $11 \mathrm{mg}$ of ascorbic acid and dissolved in 11 $\mathrm{mL}$ of methanol to obtain a stock solution of ascorbic acid with a concentration of $1000 \mathrm{ppm}$. Furthermore, $4 \mathrm{~mL}$ of ascorbic acid were taken with the respective concentrations of o ppm, 1 ppm, 2 ppm, 3 ppm, 4 ppm, and 5 ppm from the stock solution. Each tube was added with $1 \mathrm{~mL}$ of DPPH solution, incubated, then inserted into a $1 \times 1 \mathrm{~cm} 2$ cuvette and the antioxidant activity was read on a UV-Vis spectrophotometer.

Measurement of Antioxidant Activity. Measurement of antioxidant activity begun by entering a stock solution of $4 \mathrm{~mL}$ of simplicia with a concentration of o ppm, 1.25 ppm, 2.5 ppm, 5 ppm, 
$10 \mathrm{ppm}$, and $20 \mathrm{ppm}$ into the tube. Each tube was added with $1 \mathrm{~mL}$ of DPPH solution and incubated for 30 minutes. The antioxidant activity was read by inserting each tube into a $1 \times 1 \mathrm{~cm} 2$ cuvette and reading it on a UV-Vis spectrophotometer with a wavelength of $517 \mathrm{~nm} .{ }^{15}$ The same treatment was carried out on the ethanol extract of red pomegranate peel with the same concentration.

Preparation of Red Pomegranate Peel

Powder. A total of seven red pomegranates were washed with running tap water, peeled, peeled, then cut the red pomegranate peel to a size of $1 \times 1$ $\mathrm{cm}^{2}$ so that the weight of the red pomegranate peel was 420 grams. The pieces of red pomegranate pee were dried for 3 days at room temperature to obtain a dry weight of $280 \mathrm{~g}$, then mashed in a blender until they became a powder. The fine powder was separated from the coarse powder. The fine powder of red pomegranate peel was obtained as much as 105 grams.

Preparation of Red Pomegranate Peel Ethanol Extract. The extraction of red pomegranate peel was carried out using the maceration method with $70 \%$ ethanol. The filtrate obtained was 4,000 $\mathrm{mL}$ in each filtering process. Filtering was carried out 3 times so that a total of $12,000 \mathrm{~mL}$ of brown filtrate was obtained. The filtrate obtained was concentrated using a vacuum rotary evaporator. The ethanol solvent evaporation was carried out at $50^{\circ} \mathrm{C}$. The results of the evaporation process obtained a weight of $30.434 \mathrm{~g}$ of red pomegranate peel ethanol extract so that the yield of red pomegranate peel ethanol extract was $73.14 \%$.

Determination of percent inhibition of antioxidant activity. Starting with the dilution of the test sample with DPPH which was carried out in accordance with Table 1. All solutions were put into a test tube, then incubated at room temperature for 30 minutes, counting from the addition of the DPPH solution. Next, measure the absorbance at $\lambda$ DPPH which is $517 \mathrm{~nm}$. The percentage of inhibition of antioxidant activity can be calculated using equation (1). The test was carried out 3 times repetition.

$\%$ inhibition $=\left(A_{0}-A_{1} / A_{0}\right) \times 100 \%$

Note: $\quad A_{0}=$ absorbance blank (methanol)

$A_{1}=$ absorbance of sampel (extract)

Table 1. Simplicia Dilution Test with DPPH

\begin{tabular}{cccc}
\hline \hline $\begin{array}{c}\text { Concentration } \\
(\mathrm{ppm})\end{array}$ & $\begin{array}{c}\text { Test } \\
\text { Simplicia } \\
\text { Solution } \\
(\mu \mathrm{L})\end{array}$ & $\begin{array}{c}\text { Water } \\
(\mu \mathrm{L})\end{array}$ & $\begin{array}{c}\text { DPPH 160 } \\
\text { ppm }(\mu \mathrm{L})\end{array}$ \\
\hline Blank & 0 & 4000 & 1000
\end{tabular}

\begin{tabular}{cccc}
1.25 & 62.5 & 3937.5 & 1000 \\
2.5 & 125 & 3875 & 1000 \\
5 & 250 & 3750 & 1000 \\
10 & 500 & 3500 & 1000 \\
20 & 1000 & 3000 & 1000 \\
\hline
\end{tabular}

Antioxidant Activity Test. This test was to measure the antioxidant activity quantitatively by measuring the DPPH radical scavenging using a UVVis spectrophotometer. The value of free radical reduction activity was expressed by $I C_{50}$. The $I C_{50}$ describes the concentration of the simplicia that can capture $50 \%$ free radicals through a linear regression equation. The linear regression equation states the relationship between the concentration of the test compound ( $x$ ) and \% inhibition ( $y$ ).

The regression equation is $y=b x+a$; where $a$ is the intercept, $b$ is the slope and $r^{2}$ is the correlation coefficient. The value of $r^{2}$ is either close to -1 or +1 depending on the slope value obtained. ${ }^{16}$ Thus the $\mathrm{IC}_{50}$ formula can be stated as follows:

$$
\mathrm{IC}_{50}=\frac{50-\mathrm{a}}{\mathrm{b}}
$$

\section{RESULT}

The percentage of inhibition in each group is presented in Table 2 . Table 2 shows that the percentage of inhibition of red pomegranate peel tea ranged from $4.12 \%-35.51 \%$ with an average absorbance of $0.503-0.780$. The ethanol extract of red pomegranate peel has the percentage of inhibition ranging from 5.16\%-94.87\% with an average absorbance ranging from 0.047-0.911. It means that the red pomegranate peel ethanol extract has better potential as an antioxidant than the red pomegranate peel tea steeping.

Table 2. Percentage Inhibition of Steeping Tea, Ethanol Extract of Pomegranate Peel and Ascorbic Acid

\begin{tabular}{cccc}
\hline Sample & $\begin{array}{c}\text { Concentration } \\
(\mathrm{ppm})\end{array}$ & $\begin{array}{c}\text { Absorbance } \\
\text { in Average } \\
(\mathrm{nm})\end{array}$ & $\begin{array}{c}\text { Percentage } \\
\text { Inhibition } \\
(\%)\end{array}$ \\
\hline Steeping & 0 & $0.780 \pm 0.085$ & \\
$P$. & 1.25 & $0.747 \pm 0.070$ & 4.12 \\
granatum & 2.5 & $0.709 \pm 0.075$ & 9.06 \\
peel Tea & 5 & $0.664 \pm 0.081$ & 14.92 \\
& 10 & $0.503 \pm 0.064$ & 35.51 \\
\hline Ethanol & 20 & $0.359 \pm 0.042$ & 53.98 \\
Extract & 0 & $0.911 \pm 0.017$ & \\
of $P$. & 2,5 & $0.864 \pm 0.023$ & 5.16 \\
granatum & 5 & $0.799 \pm 0.014$ & 12.26 \\
peel & 10 & $0.626 \pm 0.004$ & 31.27 \\
& 20 & $0.344 \pm 0.017$ & 62.26 \\
\hline Ascorbic & 0 & $0.047 \pm 0.006$ & 94.87 \\
Acid & 1 & $0.874 \pm 0.000$ & \\
\hline
\end{tabular}




\begin{tabular}{llcl}
\hline (Positive & 2 & $0.582 \pm 0.015$ & 33.37 \\
Control) & 3 & $0.435 \pm 0.026$ & 50.99 \\
& 4 & $0.306 \pm 0.006$ & 64.95 \\
& 5 & $0.179 \pm 0.010$ & 79.52 \\
\hline
\end{tabular}

The determination of antioxidant properties based on the $\mathrm{IC}_{50}$ by making a regression equation between the \% inhibition value (Table 2 ; y) and the amount of concentration ( $x)$. The regression results are shown in Figure 2.

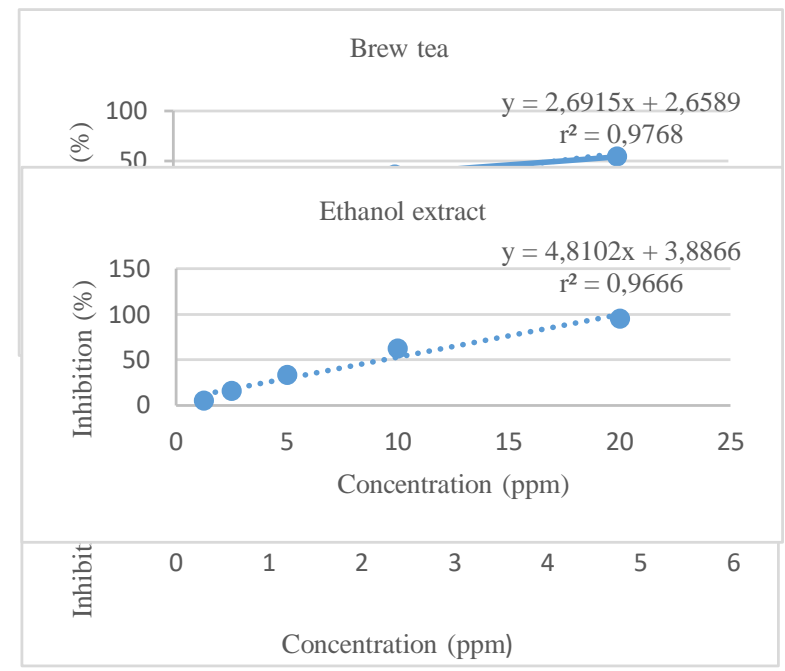

Figure 2. Regression Result between the \% Inhibition (y) and the amount of concentration (x)

Table 3. Results of One Way ANOVA for the Percentage of Inhibition

\begin{tabular}{ccc}
\hline Variable & Test Sample & $\mathrm{P}$ \\
\hline \multirow{4}{*}{ Inhibition } & $\begin{array}{c}\text { Pomegranate peel tea } \\
\text { Ethanol Extract of } \\
\end{array}$ & 0.000 \\
& $\begin{array}{c}\text { Pomegranate } \\
\text { Ascorbic acid }\end{array}$ & 0.000 \\
& & 0.000 \\
\hline
\end{tabular}

Table 4. Result of Duncan Test for the Percentage of Inhibition

Table 3 shows that there is a significant difference in antioxidant activity between the test samples ( $p$ <0.05), and is followed by the Duncan test whose results are shown in Table 4 . In Table 4, it appears that each addition in the concentration of the test sample results in a significant difference in the percentage of inhibition. In the form of ethanol extract, red pomegranate peel has an average\% inhibition greater than steeping tea at all concentrations, but the greatest is at a concentration of $20 \mathrm{ppm}$ (95.023\%).

Analysis was also carried out to determine the significance of the difference in the $I C_{50}$ among the test samples. The result of oneway Anova showed that there was no significant difference in the $I C_{50}$ among the test samples $(p>0.05)$. These results indicate that the antioxidant activity of steeping and red pomegranate peel extract is as great as ascorbic acid.

\section{DISCUSSION}

This study proves that the red pomegranate peel both in the tea preparation and in the extract has the same antioxidant activity as ascorbic acid. Antioxidants are compounds that can reduce the level of reactivity of a substrate. The mechanism of antioxidant compounds in reducing reactivity includes transfer of hydrogen atoms, transfer of single electrons, and the ability to chelate transition metals. ${ }^{18}$ Antioxidant molecules available naturally are divided into two categories, namely nonenzymatic antioxidants and enzymatic antioxidants. Compounds classified as enzymatic antioxidants include superoxide dismutase (SOD), glutathione peroxidase, and catalase. In general, compounds classified as non-enzymatic antioxidants include vitamin C, vitamin E, vitamin A, glutathione, and flavonoids. ${ }^{9}$

The efficacy of red pomegranate is due to the presence of various polyphenol compounds which have very high antioxidant activity. ${ }^{20}$ Many studies have revealed the efficacy of red pomegranate. According to Afaq (2006), ${ }^{7}$ polyphenolic compounds possessed by red pomegranates are punicalagin (elagitanin), which has been shown to have strong antioxidant, antiinflammatory, and anti-carcinogenic activity. Apart from being anti-carcinogenic, red pomegranate can also prevent premature aging due to exposure to UV-A and UV-B rays. ${ }^{7}$ The anti-carcinogenic properties are probably due to the antiproliferative and apoptotic properties of red pomegranate due to the presence of punicalagin which can inhibit

\begin{tabular}{ccc}
\hline & \multicolumn{2}{c}{ \% Inhibition in Average } \\
\cline { 2 - 3 } $\begin{array}{c}\text { Concentration } \\
(\text { ppm) }\end{array}$ & $\begin{array}{c}\text { Steeping Red } \\
\text { Pomegranate } \\
\text { Peel Tea }\end{array}$ & $\begin{array}{c}\text { Ethanol extract } \\
\text { of Red } \\
\text { Pomegranate } \\
\text { Peel }\end{array}$ \\
\hline 1.25 & $4.120^{\mathrm{e}}$ & $5.160^{\mathrm{e}}$ \\
2.5 & $9.060^{\mathrm{d}}$ & $12.263^{\mathrm{d}}$ \\
5 & $14.923^{\mathrm{c}}$ & $31.276^{\mathrm{c}}$ \\
10 & $35.153^{\mathrm{b}}$ & $62.600^{\mathrm{b}}$ \\
20 & $53.983^{\mathrm{a}}$ & $95.023^{\mathrm{a}}$ \\
\hline
\end{tabular}

peroxidation lipids which are equivalent to synthetic antioxidants. ${ }^{9}$ Other studies have shown that fresh red pomegranate fruit extract and its fermentation can prevent the proliferation of HL-60 leukemia cells. ${ }^{9}$ 
Elagitanin contained in red pomegranate can have antioxidant properties. Under in vivo physiological conditions, elagitanin will be hydrolyzed to elagic acid. Administration of elagic acid to human peel fibroblasts in vitro showed increased expression of collagen type $1 \mathrm{~m}$-RNA and could inhibit MMP-1 (matrix metalloproteinase-1), an enzyme that degrades collagen. The process of inhibiting collagen-degrading enzymes can inhibit the effects of premature aging. The effect of inhibiting aging is also due to the presence of anthocyanins. Anthocyanins contained in red pomegranate consist of delfinidin-3-glucoside, cyanidin-3-glucoside, delfinidin-3,5-diglucoside, cyanidin-3,5-diglucoside, and pelargonidin. Anthocyanins protect collagen through an inhibitory mechanism of phosphorylation of tyrosine kinase, an enzyme inactivation of epidermal growth factor (EGF).$^{21}$

In this study, it also appears that the red pomegranate peel on the ethanol extract preparation has a higher antioxidant activity than steeping tea. This is due to the level of the punicalagin compound in each sample. The extract sample is a sample that has a better punkalagin purity level than samples derived from processed tea brewed products. This has implications for the effectiveness of punicalagin activity as an antioxidant. The total content of punicalagin derived from pomegranate extract ranged from 98.70-118.60 in the Desi, Kandhari, and Badana varieties. ${ }^{22}$ In addition, the samples derived from tea brewing had low punicalagin purity, so the activity of punicalagin was less effective in these samples. Some of the polyphenol compounds contained in red pomegranates include elagic acid, gallic acid, punicalagin A, and punicalagin B. ${ }^{23}$

It can be summarized that pomegranate, including its peel, can be used as antioxidants, antiinflammatory, anti-aging and anti-cancer properties. The presentation can be in various forms such as fresh fruit, fermentation, extract or brew. ${ }^{23}$

\section{CONCLUSION}

Steeping red pomegranate peel tea and red pomegranate peel ethanol extract have the same strong antioxidant activity as ascorbic acid. The ethanol extract of red pomegranate peel has higher antioxidant activity than steeping tea from red pomegranate peel.

\section{REFERENCES}

1. Suwarni S, Setiawan S, Syatibi MM. Hubungan Usia Demensia dan Kemampuan Fungsional pada Lansia. J Keterapian Fis. 2017 May 8;2(1):3441.

2. Rabe JH, Mamelak AJ, McElgunn PJS, Morison WL, Sauder DN. Photoaging: Mechanisms and repair. J Am Acad Dermatol. 2006 Jul 1;55(1):1-19.

3. Pangkahila W. Anti Aging Medicine: Memperlambat Penuaan, Meningkatkan Kualitas Hidup. Jakarta: Penerbit Buku Kompas; 2011.

4. Gary J Fisher, Sewon Kang, James Varani, Zsuzsanna Bata-Csorgo, Yinsheng Wan, Subhash Datta, et al. Mechanisms of photoaging and chronological peel aging. Arch Dematol. 2002;138:1462-70.

5. Wahyuningsih KA. Astaxanthin Memberikan Efek Proteksi terhadap Photoaging. Damianus J Med. 2011 Oct 1;10(3):149-160-160.

6. Wahyono P, Soetjipto, Harjanto, Suhariningsih. Efek jus buah tomat (Lycopersicum pyriforme) terhadap pencegahan fotoaging kulit akibat iradiasi sinar ultraviolet-B. J Bina Praja. 2011;3(13):169-77.

7. Afaq F, Mukhtar H. Botanical antioxidants in the prevention of photocarcinogenesis and photoaging. Exp Dermatol. 2006;15(9):678-84.

8. Seeram NP, Adams LS, Henning SM, Niu Y, Zhang Y, Nair MG, et al. In vitro antiproliferative, apoptotic and antioxidant activities of punicalagin, ellagic acid and a total pomegranate tannin extract are enhanced in combination with other polyphenols as found in pomegranate juice. J Nutr Biochem. 2005 Jun 1;16(6):360-7.

9. Kawaii S, Lansky EP. Differentiation-Promoting Activity of Pomegranate (Punica granatum) Fruit Extracts in HL-60 Human Promyelocytic Leukemia Cells. J Med Food. 2004 Apr 1;7(1):13-8.

10. Jurenka JS. Therapeutic applications of pomegranate (Punica granatum L.): a review. Altern Med Rev J Clin Ther. 2008 Jun;13(2):12844.

11. Lansky EP, Newman RA. Punica granatum (pomegranate) and its potential for prevention and treatment of inflammation and cancer. $J$ Ethnopharmacol. 2007 Jan 19;109(2):177-206.

12. Dewata IP, W PAS, Widarta IWR. Pengaruh Suhu dan Lama Penyeduhan Terhadap Aktivitas Antioksidan dan Sifat Sensoris Teh Herbal Daun Alpukat (Persea americana Mill.). J Ilmu dan Teknol Pangan ITEPA. 2017 Aug 31;6(2):30-9.

13. Handayani V, Ahmad AR, Sudir M. Uji Aktivitas Antioksidan Ekstrak Metanol Bunga dan Daun Patikala (Etlingera elatior (Jack) R.M.Sm) 
Menggunakan Metode DPPH. Pharm Sci Res PSR. 2016 Sep 21;1(2):86-93-93.

14. Sutriandi A, Maulana IT, Sadiyah ER. Pengaruh Metode Pengeringan terhadap Mutu Ekstrak Biji Kara Benguk (Mucuna pruriens (L.) DC.) yang Dihasilkan. Pros Farm. 2016 Aug 11;0(0):710-6.

15. Arokiyaraj S, Martin S, Perinbam K, Arockianathan PM, Beatrice V. Free Radical Scavenging Activity and HPTLC Fingerprint of Pterocarpus santalinus L. - an in vitro study. Indian J Sci Technol. 2008: 1(7):1-3

16. Nurliyana R, Syed Zahir I, Mustapha Suleiman K, Aisyah MR, Kamarul Rahim K. Antioxidant study of pulps and peels of dragon fruits: a comparative study. Int Food Res J. 2010;17(2).

17. Molyneux $P$. The use of the stable free radical diphenylpicrylhydrazyl (DPPH) for estimating antioxidant. Songklanakarin J Sci Technol SJST. 2004 Mar 1;26(2):211-9.

18. Santos-Sánchez NF, Salas-Coronado R, Villanueva-Cañongo C, Hernández-Carlos B. Antioxidant Compounds and Their Antioxidant Mechanism. Antioxidants [Internet]. 2019 Mar 22 [cited 2020 Sep 21]; Available from: https://www.intechopen.com/books/antioxidant s/antioxidant-compounds-and-their-antioxidantmechanism

19. Shrivastava A, Aggarwal LM, Mishra SP, Khanna HD, Shahi UP, Pradhan S. Free radicals and antioxidants in normal versus cancerous cells An overview. Indian J Biochem Biophys IJBB. 2019 Aug 26;56(1):7-19-19.

20. Wiryowidagdo S. Kimia dan Farmakologi Bahan Alam. 2nd ed. Jakarta: Penerbit Buku Kedokteran EGC; 2008.

21. Bei R, Masuelli L, Turriziani M, Volti GL, Malaguarnera $M$, Galvano F. Impaired Expression and Function of Signaling Pathway Enzymes by Anthocyanins: Role on Cancer Prevention and Progression. Curr Enzyme Inhib. 2009 Dec 1;5(4):184-97.

22. Khalil AA, Khan MR, Shabbir MA, Rahman KU. Comparison of antioxidative potential and punicalagin content of pomegranate peels. $J$ Anim Plant Sci. 2017;27(2):522-7.

23. Singh $M$, Jha A, Kumar A, Hettiarachchy N, Rai AK, Sharma D. Influence of the solvents on the extraction of major phenolic compounds (punicalagin, ellagic acid and gallic acid) and their antioxidant activities in pomegranate aril. J Food Sci Technol. 2014 Sep 1;51(9):2070-7. 